\title{
フェムト秒レーザー励起二光子蛍光顕微鏡法を用いた 表面プラズモンポラリトンのイメージング
}

\author{
服部 竜己 ${ }^{1, \dagger}$, 久保 敦 ${ }^{1}$, 小栗 克弥 ${ }^{2}$, 中野 秀俊 ${ }^{2}$, 宮崎 英樹 ${ }^{3}$ \\ 1筑波大学大学院数理物質科学研究科 (†305-8571 茨城県つくば市天王台1-1-1) \\ ${ }^{2} \mathrm{NTT}$ 物性科学基礎研究所 ( ₹243-0198 神奈川県厚木市森の里若宮3-1) \\ 3物質・材料研究機構（テ305-0047 茨城県つくば市千現1-2-1）
}

\section{Imaging of Surface Plasmon Polaritons Using Femtosecond Laser Excited Two-Photon Fluorescence Microscopy}

\author{
Tatsumi HATTORI,${ }^{1, \uparrow}$ Atsushi KUBO,${ }^{1}$ Katsuya OGURI,${ }^{2}$ Hidetoshi NAKANO, ${ }^{2}$ \\ and Hideki T. MIYAZAKI ${ }^{3}$ \\ ${ }^{1}$ Institute of Physics, University of Tsukuba, 1-1-1 Tennodai, Tsukuba, Ibaraki 305-8571 \\ ${ }^{2}$ NTT Basic Research Labs., NTT Corporation, 3-1 Morinosato, Wakamiya, Atsugi, Kanagawa 243-0198 \\ ${ }^{3}$ National Institute for Materials Science, 1-2-1 Sengen, Tsukuba, Ibaraki 305-0047
}

(Received May 18, 2012)

\begin{abstract}
We demonstrate imaging of surface plasmon polaritons (SPPs) on a silver film using a two-photon fluorescence microscopy technique. Surface plasmon waves launched from an edge of a silver film under a light irradiation of 11-fs near-infrared laser pulses promote formation of intensity beats in nearfields through SPP-light interference. Dye molecules embedded in a thin PMMA layer on a silver film up-convert the near-infrared surface fields to propagating lights in visible range through a two-photon excitation, which enables to image the near-fields with using a conventional optical microscope. The wavelength of SPP determined from the beat wavelength of near-fields agrees well with an evaluation using dielectric properties of sample materials and the dispersion relation of SPP.
\end{abstract}

Key Words: Surface plasmon, Femtosecond, Ultrafast laser, Fluorescence microscopy, Imaging

\section{1. はじめに}

\begin{abstract}
金属一誘電体界面を伝搬する電子密度のコヒーレント な振動である表面プラズモンポラリトン (Surface Plasmon Polariton: SPP) を情報伝達に用いるサブ波長スケー ル, ワイドバンドの超高速光素子の実現を目指し ${ }^{1)}$, 近 年SPP素子の開発に関する研究が活発に進められてい る。その結果, 金属細線型, 金属ドット配列型, V字溝 型など様々なタイプのSPP導波路や, SPPの集光器, 共 鳴器, 反射構造, 干渉構造などの光学素子 2,3$)$, またSPP エミッター ${ }^{4}$ やディテクター ${ }^{5}$ などの機能素子の開発が 急速に進んでいる。これらSPP素子の開発・評価を行う 上で重要な役割を担っているのが，種々の顕微鏡法によ るSPPの画像化技術である。顕微鏡法としては近接場光 学 顕 微 鏡 法 (Nearfield Scanning Optical Microscopy: $\mathrm{NSOM})^{6)}$, 光電子顕微鏡法 (Photoemission Electron Mi-
\end{abstract}

croscopy: PEEM $)^{7-11)}$, および蛍光顕微鏡法 ${ }^{12-15)}$ や漏れ出 し顕微鏡法 ${ }^{16)}$ などの光学顕微鏡法が代表的である.

ところで, これらの顕微鏡法で可視化されているのは 励起光源に連続発振 (cw) レーザーを用いたSPPの「静的」 な強度分布である場合がほとんどであり，将来デバイス として期待されるSPP超高速素子の開発のために重要 な, SPP波の「動的」なダイナミクスに関しては, ごく限

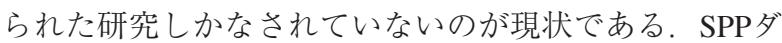
イナミクスの解明のためには，超高速時間分解分光法の 技術を顕微鏡法と組み合わせた「時間分解顕微鏡法」によ り，SPPの動きを直接可視化する方法が有効である. $\mathrm{SPP}$ のコヒーレント寿命が $10-100 \mathrm{fs}$ 程度であることを 考えれば，このような時間分解顕微鏡のもつ時間分解能 はコヒーレント寿命と同等かそれ以下であることが要求 され，10 fs程度である事が求められる。しかし，10 fsの 時間分解能を有する顕微鏡法の報告はほとんどない。こ

†現在の住所：日立ハイテクノロジーズ (†369-0395 埼玉県児玉郡上里町嘉美1600)

Present address: Hitachi High-Technologies Corporation (1600 Kami, Kamisato, Kodama, Saitama 369-0395) 
のような超高速時間分解能を実現した報告のひとつは PEEMを用いたものであり, Kubo, Petekらは近紫外 フェムト秒レーザーを用い, $10 \mathrm{fs} の$ 時間分解能での銀 (Ag)SPP波の伝搬の動画像化について報告している ${ }^{7,8)}$. ただし，近紫外光を利用しているためSPPは金属中で強 いohmic損失を生じ, SPPの伝搬長は数 $\mu \mathrm{m}$ 程度に限られ ている.

SPP減衰の強度は振動数に依存し, 低振動数側ではよ り小さくなるという特徵をもつ.このため励起光に近赤 外領域を用いれば， $\mathrm{Ag}$-真空界面SPPの伝搬長は可視 近紫外領域の場合よりも長く, $100 \mu \mathrm{m}$ 以上に伸展する 事が, $\mathrm{Ag}$ の誘電関数を用いた見積もりから示唆され $る^{17,18)}$ 。また, 今日の情報通信を支えているのは通信帯 を用いた光ファイバ網であり，そこで使用される光デバ イスと整合させる上でも近赤外域のSPPに関する知見は 重要である ${ }^{19)}$. このような光エネルギーの小さい近赤外 光をSPP励起に用いる場合, 可視化を行うには, 試料表 面からの光電子放出を要するPEEMでは高次の多光子光 電子放出を誘起しなければならず技術的な困難さが増大 する.このため近赤外SPPの画像化には光学的な顕微鏡 法が有力な候補となる。ところが，表面波であるSPPは 平坦平面上ではdark stateの一種と見なせ ${ }^{11)}$, 輻射場との 結合がごく弱い事から, 通常の光学顕微鏡法では明瞭に 観察することができない，何らかの方法で近接場を輻射 場に変換する必要がある。蛍光顕微鏡法はこのために有 効な方法であり，Ditlbacher，Krennらは波長515 nm ${ }^{12)}$, および715 $\mathrm{nm}^{13)}$ のレーザー光で励起したSPP波の空間分 布を同手法により画像化している。金属膜上に色素分子 を塗布して蛍光層とし，SPPの電場による励起で発せら れる蛍光の強度分布を光学顕微鏡とCCDカメラにより 得ている. 光学顕微鏡を用いるため空間分解能は $1 \mu \mathrm{m}$ 程度に限られるものの, 数秒程度のCCDカメラの露光 によりSPPの2次元像が得られ有用な手法である。

多光子励起蛍光過程を用い, 近赤外領域のSPPを可視 領域の信号に変換する事も可能である. Wang, Aigouy らは蛍光ビーズを走査プローブに用い，近接場による二 光子励起蛍光過程で放射される可視光を検出する事によ り, 波長975 nmの近赤外レーザーで励起されたSPPの三 次元的な強度分布の可視化を行っている ${ }^{14)}$. 周波数の アップコンバージョンにより信号検出がより容易にな り，また多光子励起過程を用いている事による空間分解 能の向上も期待できるなど，興味深い技術となる.

本論文では, 近赤外SPPの超高速ダイナミクスの解明 を目的とし，フェムト秒レーザー励起二光子蛍光顕微鏡

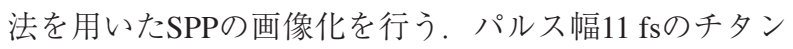
サファイアレーザーの照射により $\mathrm{Ag}$ 表面にSPPの波束を 励起し, さらに励起パルスと干渉させることで試料表面 に過渡的な近接場のビートを形成する。これにより $\mathrm{Ag}$ 薄膜上に形成した蛍光層を近接場の二光子励起過程によ り励起し, 可視領域の伝搬光として放射される蛍光を対 物レンズとCCDカメラで画像化する。一つのSPP像の取 得に必要な時間は10秒程度と走査プローブ型顕微鏡法に 比べ十分短く, 多数の画像の連続取得が必要とされる時
間分解計測にも適応できる顕微鏡法となる

\section{2. フェムト秒レーザー励起二光子蛍光顕微鏡：} 装置概要

SPPの可視化のために，チタンサファイアレーザーと 蛍光顕微鏡法を組み合わせ，フェム卜秒の時間分解能と マイクロメートルの空間分解能を有する顕微観察システ ムを構築した。 Fig. 1に装置の概要を示す ${ }^{15)}$. 光源は キャビティにチャープミラーによる群速度分散補償 ${ }^{20)}$ を 用いた自作のチタンサファイアレーザーオシレーターで あり，フリンジ分解自己相関法によるパルス波形の評価

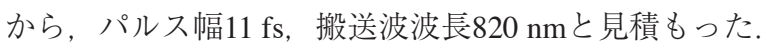
繰返し周波数と平均出力はそれぞれ，90 MHz， $400 \mathrm{~mW}$ である。これに加え，パルス幅 $20 \mathrm{fs,}$ 繰返し周波数 $75 \mathrm{MHz}$, 平均出力 $300 \mathrm{~mW}$ のタンサファイアレーザー も併せて用いた。

試料はSi基板に真空蒸着した $\mathrm{Ag}$ 薄膜であり，その上 に色素分子をドープしたPolymethilMetacrylate(PMMA) をスピンコートし蛍光層を形成する。色素には Rhodamine6G (Rh6G) およびCoumarin343(C343)を用い た。本報告ではRh6Gドープ試料1つ，C343ドープ試料2 つの，計3つの試料を用いた。それぞれの試料のPMMA 膜厚, およびAg膜厚は, Rh6Gドープ試料に対して PMMA:100 nm/Ag:40 nm, C343ドープ試料に対して PMMA:100 nm/Ag:40 nm, およびPMMA:20 nm/Ag:100 nm である. Ag膜厚は波長 $800 \mathrm{~nm}$ の光で励起されるSPPの $\mathrm{Ag}$ 側への侵入長 $(11 \mathrm{~nm})$ よりも十分厚い. 用いた 2 種類 の色素の吸収スペクトルを, チタンサファイアレーザー のスペクトルと併せてFig. 1の挿入図に示す。吸収スペ クトルのピーク波長は異なるが, 両者ともチタンサファ イアレーザーの二光子吸収により可視域に蛍光を発す る。 Rh6G, およびC343の蛍光波長は, それぞれ約 $550 \mathrm{~nm}, 460 \mathrm{~nm}$ であ。試料には, PMMA膜の形成の のち一部を $\mathrm{Ag}$ 膜とともに除去することで, 一次元の エッジ構造を形成した。レーザーパルス光はこのエッジ 構造を照射領域内に含むように, 直径約 $100 \mu \mathrm{m}$ のス

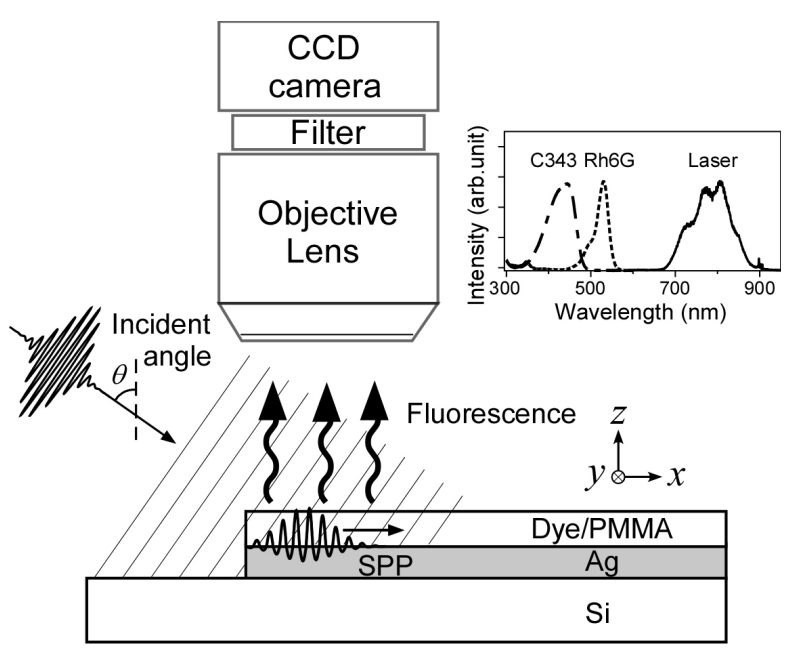

Fig. 1 Schematic of the experimental setup. ${ }^{15}$ 
ポットサイズに入射角度 $\theta て ゙$ 集光する。試料面上での照 射光のピーク強度は, パルス幅 $11 \mathrm{fs}$ および20 fsのレー

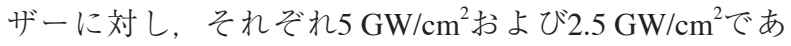
る.

平坦な金属表面上では，波数の不一致のために伝搬光 はSPPを励起することなくほぼ全ての成分が反射する。 しかし，金属表面にエッジやスリット，微小な凹凸など のナノ構造がある場合, 回折による波数の補償が生じ, 入射光の一部がSPPに結合する ${ }^{17)}$ 。本報告の試料では， 入射光の照射領域内に位置する金属膜エッジが一次元的 な光-SPP結合部として機能する。グレーティングのよ うに固有の波数を有する構造が特定の波長, 入射角の光 に対し共鳴的に応答するのに対し, 単一のエッジ構造は 光に対し幅広い波数補償を与え, 際立った共鳴を示さな いので，幅広い波長域がSPPに結合する。この特性は フェムト秒レーザーのようにスペクトル幅の広い光を SPPに結合する場合には利点となり，エッジ部では入射 パルスの電場波形を反映した超短パルス状のSPP波束が 励起される. 励起されたSPP波束はAg-PMMA界面に 沿って固有の群速度 $v_{\mathrm{SPP}}$ で伝搬し, 一方, SPP波束を励 起したパルス光の波面も入射角に対し $c / \sin \theta$ の関係で決 まる速度で試料表面を前進する。このように，一般にパ ルス光の波面がSPPの群速度よりも速い速度で前進する ため，時間の経過とともに両者の位置は離れていく。し かしエッジの近傍では両者は空間的に重なり，干渉によ る近接場のビートを形成する。試料表面の蛍光分子は主 にこの表面場の二光子過程によって励起されるため, 近 接場のビートが蛍光強度のビートとして写し取られ, 光 学顕微鏡で観察する事が可能になる。

このように，SPPを励起光と干渉させてできるビート 構造を観察する方法には, 干渉を用いずSPPのみに由来 する信号を観察する場合と比べ, 次のような利点があ る。第一に，顕微像からSPPの波長を決定する事ができ る. ビート波長 $\lambda_{\text {beat }}$ とSPP波長 $\lambda_{\mathrm{SPP}}$ との関係は, SPPの波 数と入射光の表面平行成分の波数との差, $\Delta k$ を用いて 次式で表される。

$$
\lambda_{\text {beat }}=2 \pi / \Delta k=2 \pi /\left(k_{\mathrm{SPP}}^{\prime}-k_{0} \sin \theta\right), \quad k_{0}=2 \pi / \lambda_{0},
$$

ここで, $k_{\mathrm{SPP}}^{\prime}$ はSPPの複素波数べクトル $\left(k_{\mathrm{SPP}}=k_{\mathrm{SPP}}^{\prime}+i k_{\mathrm{SPP}}^{\prime \prime}\right)$ の実部, $k_{0}$ は入射光の波数ベクトル $\left(k_{0}=2 \pi / \lambda_{0}, \lambda_{0}\right.$ : 光 波長)である. Eq. (1)が示すように, 入射角 $\theta$ の取り方 により $\lambda_{\text {beat }}$ は $\lambda_{\mathrm{SPP}}$ よりも長く，数 $\mu \mathrm{m}$ 程度に引き伸ばすこ とができるため ${ }^{6,14)}$, 通常の光学顕微鏡の空間分解能に よりビート構造を解像し, 節・腹の空間的な位置やビー 卜波長を決定する事が十分可能になる，第二に，ポンプ ープローブ法と組み合わせる事により，プラズモン波束 の伝搬の様子を「遅延時間の増大に伴うビートパターン の変位」として可視化する事ができる ${ }^{8)}$. 第三に，ビー トの空間的なパターンからSPPの位相に関する情報をも 得る事が可能である ${ }^{21)}$ 。これらの性質は入射光の照射範 囲を微小領域に限定し，SPP波の成分のみを顕微観察す る方法 ${ }^{12,13)}$ では得られないものであり, 当顕微鏡法の特 徵である。

\section{3. 表面プラズモンポラリトン波の蛍光顕微観察 : 顕微像とその解析}

本顕微鏡法では， $\mathrm{Ag}$ 薄膜のエッジ部で励起されたSPP 波は励起光と干渉し，その結果生じる表面場のビート は，エッジ部を起点としそこから連なる減衰的な振動パ ターンとして可視化される。 そのため, ビートパターン の波長や強度はSPP波の特性を反映したものとなる。こ の章では, ビート強度の励起光偏光依存性, ビート波長 の蛍光波長依存性, 励起光入射角度依存性, PMMA膜 厚依存性について議論し，それらが実際にSPP-光干涉 から予測される特徵を満足している事を示す。ビート強 度の偏光依存性からは, 蛍光色素の励起が二光子過程で あることも確認する事ができる。さらに，試料をair/ $\mathrm{PMMA} / \mathrm{Ag} / \mathrm{Si}$ の4層構造と見なした固有值方程式の解か らSPPの分散曲線が得られ, ビート波長の定量的な解析 が可能である事を示す.

Fig. 2にRh6G (a，b)，およびC343(c，d）をそれぞれ蛍 光層に用いた試料の二光子蛍光顕微鏡像を示す. 励起光 にはパルス幅11 fsのレーザーを用いた。両者とも $\mathrm{Ag}$ 層, PMMA層の厚みはPMMA: $100 \mathrm{~nm} / \mathrm{Ag}: 40 \mathrm{~nm}$ であり, SPP 波長を決定する界面領域の誘電率分布は同じである。顕 微像の左端付近に位置する $\mathrm{Ag}$ 膜のエッジ部に対し画面 左方向から入射角 $\theta=60^{\circ}$ でフェムト秒パルス光を入射し

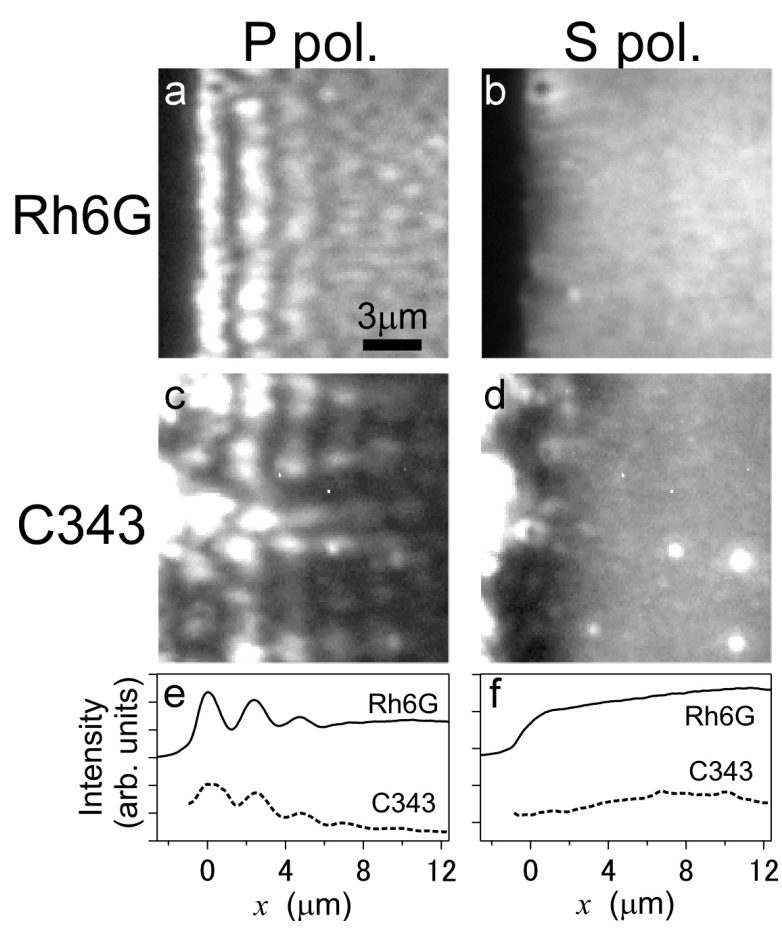

Fig. 2 Fluorescence micrographs of samples using Rh6G $(a, b)$ and C343 (c, d) as the dye molecule. The fslaser pulses irradiate samples from the left of images at the incident angle of $60^{\circ}$. For both Rh6G and C343, beat patterns appear for excitations with P-polarized light $(a, c)$, but do not for S-pol. light $(b, d)$. Intensity profiles of images are also shown (e, f). The wavelength of beat is $\lambda_{\text {beat }}=2.2 \mu \mathrm{m}$ for both Rh6G and C343. ${ }^{15}$ 
ている。 それぞれの試料について, 同一の領域をp偏光 (a， c)，およびs偏光(b，d)で励起した結果を示す。ま た, 各顕微像を画面縦方向に加算平均して得られた断面 図を (e, f) に示す。Rh6G，C343両方の試料とも，p偏光 の場合のみ, エッジ部から $+x$ 軸方向(画面右方向)に向 かって減衰しながら振動するビートパターンが明瞭に視 認される. s偏光ではこのようなビート構造は見られず, 顕微像は一様な強度分布を示している。 この偏光依存性 はSPPがTM波であることに由来しており，光の入射面 に平行な電場成分を有する $\mathrm{p}$ 偏光の場合にのみ光-SPP結 合が生じる事を示している ${ }^{14)}$

ビート波長はFig. 2 (e)に見られるようにRh6G，C343 ともに同一であり $2.2 \mu \mathrm{m}$ であった。前節で述べたように 2つの色素はチタンサファイアレーザーで2光子励起され るものの, 蛍光波長が異なるため, Rh6Gでは約 $550 \mathrm{~nm}$, C343では約450 nmの波長帯域をそれぞれバンドパス フィルタで切り出し, 画像化している. ビート波長が検 出する光波長に依存せず一定である事は, ビートが $\mathrm{SPP}$ 励起光の干渉に由来する事を裏付ける証拠のひと つになる。 なお, 顕微像から得られたビート波長より, Eq. (1) を用い $\lambda_{\mathrm{SPP}}$ は635 nmと求められるが, これは $\mathrm{Ag}$-大気界面でのSPP波長 $807 \mathrm{~nm}$ と, Ag-PMMA界面で の波長547 nmとの中間的な值である. PMMA薄膜が塗 布されたことにより $\mathrm{Ag}$ 表面の実効的な屈折率が高くな り，SPP波長の短縮が生じている，ビート波長，あるい はSPP波長の定量的な評価については後に述べる。

SPP波長は励起光の波長と試料表面領域の誘電率によ り一意に決定されるが, Eq. (1)より, ビート波長は励 起光の入射角 $\theta$ に依存して変化する. これは励起光の波 数べクトルの表面平行成分の大きさが $k_{0} \sin \theta$ となるた め, SPP と光との波数の差 $\Delta k$ が入射角の増大とともに減 少するからであり, これに伴いビート波長は伸展する。

このようにビート波長が $\theta$ に依存した変化を示すこと は, 観察されるビート構造がSPP-光干渉に起因する事 を確認する根拠になる. Fig. 3 (a)に, Rh6G試料につい て $\theta=45,60$, および $75^{\circ}$ で観察した顕微像を，（b)にそ れらの断面図を示す. ビート波長は $\theta$ が大きくなるとと

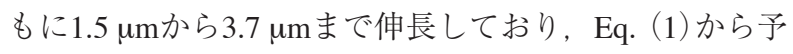
想される傾向と一致する. $\theta$ に対する $\lambda_{\text {beat }}$ の変化のグラ フをFig. 3 (c) に示す. 前述のように, 試料表面に存在 するPMMA薄膜のため $\lambda_{\mathrm{SP}}$ は $\mathrm{Ag}-$ 大気界面よりも短縮し, これにより $\Delta k$ は増大するため, どの入射角に対しても $\lambda_{\text {beat }}$ の值はAg-大気界面における值 (Fig. 3 (c) 点線)より も短くなっている. $\lambda_{\text {beat }}$ の $\theta$ 依存性は, 後に述べる有限 厚さのPMMAとAg膜の効果を取り入れたモデル (Fig. 3 (c) 実線)により良く説明できる.

また，顕微鏡下でビートパターンがコントラスト良く 観察されることから, 蛍光層の励起には, 入射光電場な らびにSPP電場が同程度の割合で寄与していることが推 察される。フエムト秒レーザー励起PEEMによる研究 で, SPP-光干渉ビートの形状は, SPP と励起光との相対 的な強度比によって変化する事が, 実験とシミュレー ションとの比較から示されている ${ }^{10)}$. Fig. $3(\mathrm{~b})$ において
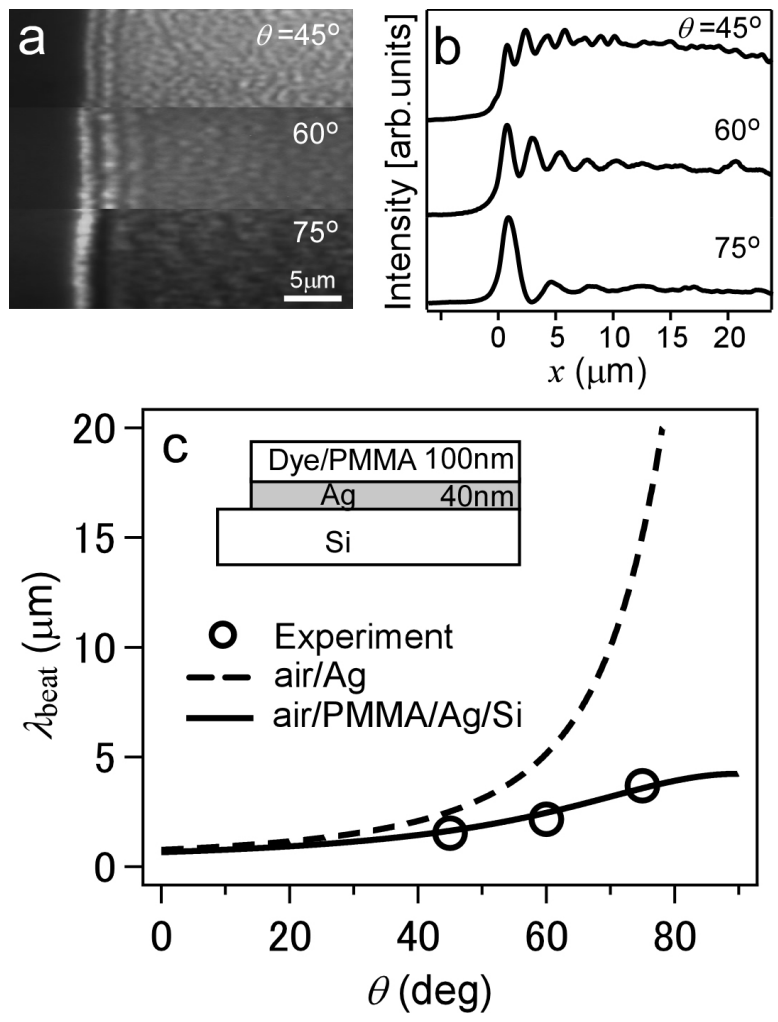

Fig. 3 Light incident angle dependence of the beat wavelength. Fluorescence micrographs of the sample taken at the incident angle of $45^{\circ}, 60^{\circ}$ and $75^{\circ}$ (a), and corresponding intensity profiles (b). The thickness of PMMA and Ag films are $100 \mathrm{~nm}$ and $40 \mathrm{~nm}$, respectively. (c) Beat wavelengths ( $\left.\lambda_{\text {beat }}\right)$ of micrographs (open circle) and calculated ones using SPP wavelengths determined from the two-layer model (air/Ag, dashed line) and from the fourlayer model (air/PMMA/Ag/Si, solid line). ${ }^{15)}$

$x<0$ の領域は蛍光膜が除去されており，信号強度がゼ ロの基準になる。 $\theta=75^{\circ}$ ではビートの谷の部分で信号強 度がほぼゼロまで低下しており，入射光とSPPとがほと んど完全に相殺されている事から，入射電場とSPP電場 がほぼ等しい強度を持つことが分かる。一方，入射角が 表面垂直方向へシフトした $\theta=45^{\circ}$ ではビートパターンの 様相は異なり，一定の背景強度を基準に，相対的に小振 幅のビートが上下に対照的な振動を示す。入射光による 蛍光の直接励起の割合が大きくなったことが $x>0$ の領 域の背景強度を形成する要因となっている。

PMMA薄膜により生じる $\lambda_{\text {beat }}$ の短縮の程度は, $\mathrm{Ag}$ 膜の 対面となる誘電体部の屈折率の増大に起因しており PMMAの膜厚に依存する. 励起光にパルス幅 $20 \mathrm{fs} の$ レーザーを用い, PMMA薄膜の厚みが $20 \mathrm{~nm}$ とよ薄い 試料 (C343, PMMA: $20 \mathrm{~nm} / \mathrm{Ag}: 100 \mathrm{~nm})$ について, $\lambda_{\text {beat }}$ の $\theta$ 依存性を測定した。 Fig. 4に代表的な顕微像 (a) と, それ らの断面図(b) を示す. PMMA膜厚が100 nmの場合 (Fig. 3) と同様, Ag膜のエッジ部から $+x$ 方向に減衰的に 振動するビートパターンが視認され，また うビート波長の伸展が見られる。パルスレーザーの時間 幅が長くなったこと，ならびにPMMA膜厚が薄く均一 
で表面荒れによる散乱が低減されたことにより，Fig. 3 に比較してビートの減衰距離が長くなっている，入射角 $\theta: 45-75^{\circ}$ に対し， $\lambda_{\text {beat }}$ の值は2.6-11.1 umとなったが, この值はPMMA膜厚 $100 \mathrm{~nm}$ の場合に比べて長く, より $\mathrm{Ag}$-大気界面に㧍ける值 (Fig. 4 (c) 点線)に近づいてい る。このように $\lambda_{\mathrm{SPP}}$ はPMMA膜厚に依存して繊細に変化 するが，この性質は界面領域におけるSPP電場の表面垂 直方向の分布の様相を反映したものである.SPPの電場 強度は金属 $(\mathrm{Ag})$-誘電体界面で最大でありそこから離れ るにつれ指数関数的に減衰し, 誘電体が大気の場合約 $300 \mathrm{~nm}$ の減衰長を有する。このため表面近傍の誘電率 の変化に対し表面プラズモンの波長は敏感に影響を受 け，かつその程度は〜数100 nmに至るまで膜厚に依存 して変化する。

このような, 誘電体薄膜で被覆された金属表面におけ る表面プラズモン波長を定量的に評価するには, 多層膜 試料に対する表面電磁場モードを解析し表面プラズモン
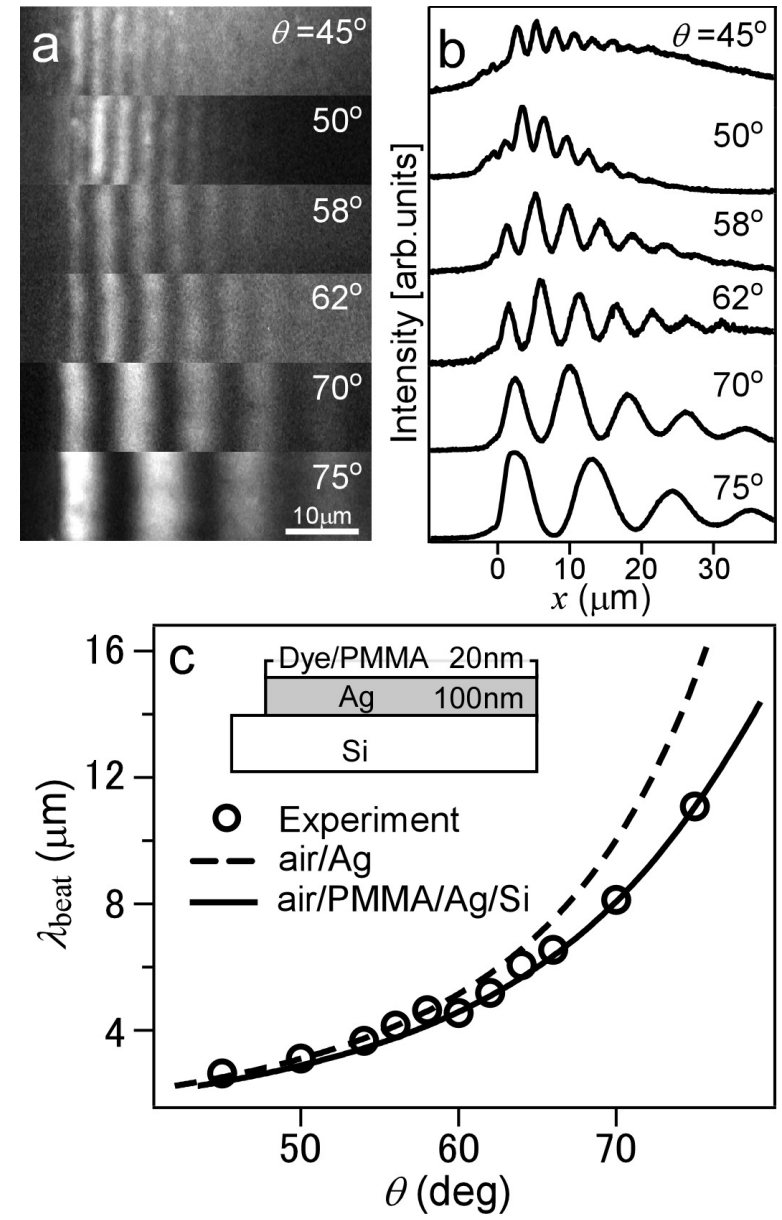

Fig. 4 Light incident angle dependence of the beat wavelength. Selected fluorescence micrographs of the sample taken at the incident angle of $45^{\circ}-75^{\circ}$ (a), and corresponding intensity profiles (b). The thickness of PMMA and Ag films are $20 \mathrm{~nm}$ and $100 \mathrm{~nm}$, respectively. (c) Beat wavelengths $\left(\lambda_{\text {beat }}\right)$ of micrographs (open circle) and calculated ones using SPP wavelengths determined from the twolayer model (air/Ag, dashed line) and from the four-layer model (air/PMMA/Ag/Si, solid line).
の分散関係を導出すれば良い。これを行うため，試料を 大気 (air)/PMMA/Ag/基板 $(\mathrm{Si})$ の層構造でモデル化し, PMMA とAg膜の有限な膜厚の効果を取り入れる。表面 プラズモンの分散関倸は多層膜に対する固有值方程式を 解く事で得られ，一般的には数值解法が必要であるが, 今回のような4層構造についてはPockrandによりSPPの波 数べクトル $k_{\mathrm{SPP}}$ を物質の誘電関数の陽関数として解いた 近似式が求められており, 以下の様に書ける22,23).

$$
\begin{aligned}
& k_{\mathrm{SPP}}=k_{x}^{0}+k_{x}^{1 \mathrm{C}}+k_{x}^{1 \mathrm{R}}+k_{x}^{2 \mathrm{C}}+k_{x}^{2 \mathrm{R}}+k_{x}^{2 \mathrm{CR}} \\
& k_{x}^{0}=\frac{\omega}{c}\left(\frac{\varepsilon_{1} \varepsilon_{3}}{\varepsilon_{1}+\varepsilon_{3}}\right)^{1 / 2} \\
& k_{x}^{1 \mathrm{C}}=\frac{\omega}{c}\left(\frac{\varepsilon_{2}^{\prime}-\varepsilon_{3}}{\varepsilon_{2}^{\prime}}\right)\left(\frac{\varepsilon_{\varepsilon^{\prime}}^{\prime} \varepsilon_{3}}{\varepsilon_{1}^{\prime}+\varepsilon_{3}}\right)^{2} \\
& \left(\frac{\varepsilon_{2}^{\prime}-\varepsilon_{1}^{\prime}}{\varepsilon_{3}-\varepsilon_{1}^{\prime}}\right)\left(-\varepsilon_{1}^{\prime} \varepsilon_{3}\right)^{-1 / 2}\left(\frac{2 \pi d_{2}}{\lambda_{0}}\right) \\
& k_{x}^{1 \mathrm{R}}=\frac{\omega}{c} r_{01}\left(\frac{2}{\varepsilon_{3}-\varepsilon_{1}^{\prime}}\right)\left(\frac{\varepsilon_{1}^{\prime} \varepsilon_{3}}{\varepsilon_{1}^{\prime}+\varepsilon_{3}}\right)^{3 / 2} \\
& \exp \left(-2 \frac{2 \pi d_{1}}{\lambda_{0}} \frac{-\varepsilon_{1}^{\prime}}{\left(-\varepsilon_{1}^{\prime}-\varepsilon_{3}^{\prime}\right)^{1 / 2}}\right) \\
& k_{x}^{2 \mathrm{C}}=k_{x}^{1 \mathrm{C}}\left[\frac{1}{2} \frac{k_{x}^{1 \mathrm{C}}}{\operatorname{Re}\left[k_{x}^{0}\right]}\left(2 \frac{2 \varepsilon_{3}^{2}-\varepsilon_{2}^{\prime 2}}{\varepsilon_{3}\left(\varepsilon_{3}-\varepsilon_{2}^{\prime}\right)}\right)\right. \\
& \left.+\frac{\varepsilon_{1}^{\prime}+\varepsilon_{3}}{-\varepsilon_{3}}-i \frac{\varepsilon_{1}^{\prime \prime}}{2 \varepsilon_{1}^{\prime}}\right] \\
& k_{x}^{2 \mathrm{R}}=k_{x}^{1 \mathrm{R}}\left[\frac{1}{2} \frac{k_{x}^{1 \mathrm{R}}}{\operatorname{Re}\left[k_{x}^{0}\right]}\left(\frac{2 \varepsilon_{1}^{\prime}+\varepsilon_{3}}{-\varepsilon_{3}}\right)-i \frac{\varepsilon_{1}^{\prime \prime}}{\varepsilon_{1}^{\prime}-\varepsilon_{3}}\right] \\
& k_{x}^{2 \mathrm{CR}}=\frac{k_{x}^{\mathrm{IR}} k_{x}^{1 \mathrm{C}}}{\operatorname{Re}\left[k_{x}^{0}\right]}\left[-\frac{\varepsilon_{1}^{\prime}}{\varepsilon_{3}}+\frac{2 \varepsilon_{3}}{\varepsilon_{3}-\varepsilon_{2}^{\prime}}+\frac{\varepsilon_{2}^{\prime}}{2 \varepsilon_{3}}\right] \\
& r_{01}=\left(\frac{k_{1 z}}{\varepsilon_{1}}-\frac{k_{0 z}}{\varepsilon_{0}}\right) /\left(\frac{k_{1 z}}{\varepsilon_{1}}+\frac{k_{0 z}}{\varepsilon_{0}}\right) \\
& k_{i z}=\left[\varepsilon_{i}(\omega / c)^{2}-k_{x}^{2}\right]^{1 / 2}(i=0,1)
\end{aligned}
$$

但し，式中の下付き添え字 $0 ， 1 ， 2 ， 3$ はそれぞれ $\mathrm{Si}$, $\mathrm{Ag}$, PMMA, airを指 $L, \quad \varepsilon_{0}=\varepsilon_{0}^{\prime}+i \varepsilon_{0}^{\prime \prime}, \quad \varepsilon_{1}=\varepsilon_{1}^{\prime}+i \varepsilon_{1}^{\prime \prime}$, $\varepsilon_{2}=\varepsilon_{2}^{\prime}+i \varepsilon_{2}^{\prime \prime}, \varepsilon_{3}(=1)$ はそれぞれ $\mathrm{Si}, \mathrm{Ag}$, PMMA，airの 誘電関数である。 また， $d_{\mathrm{i}}$ は $i$ 層の膜厚， $r_{01}$ は $\mathrm{Si} / \mathrm{Ag}$ 界面 での複素反射係数である。

$k_{S P P}$ はEq. (2)に示すように6個の要素で表されるが, そのうち第一項 (Eq. (3)) はよく知られる金属一誘電体2 層界面に㧍けるSPPの分散関係であり, 今回の場合 $\mathrm{Ag}^{-}$ 大気界面に㧈けるSPPに相当する。これに対し， $\mathrm{Ag}$ 表面 にコートされた誘電体層の効果 (Eq. (4)), Ag膜厚が薄 い場合に現れる放射結合の効果 (Eq. (5))，扔よびそれ らの高次項 (Eq. (6-8))が補正項として加わっている.

Fig. 5に, $\mathrm{Ag}^{18)}$ および $\mathrm{Si}^{24)}$ の誘電関数に文献值を, PMMAの誘電関数に分光エリプソメトリーにより実験 的に決定した值 $\left(\lambda_{0}=800 \mathrm{~nm}\right.$ に対し $\left.\varepsilon_{2}=2.1\right)$ をそれぞれ用 い, 表面層の膜厚がPMMA:20 nm/Ag:100 nm(Fig. 5 点 
線), およびPMMA:100 nm/Ag:40 nm(Fig. 5実線)の2事例 についてEq. (2)により導出したSPPの分散曲線を示す. 比較のため, Eq. (3)を用いた $\mathrm{Ag}$-大気界面SPPの分散曲 線 (Fig. 5破線)，および $\theta=60^{\circ}$ のライトライン (Fig. 5一 点鎖線)を併せて示す。また，挿入図に励起パルスの搬 送波周波数 $\left(\omega_{0}\right)$ 付近に扮ける拡大図を示す。2事例とも SPPの分散曲線はAg-大気界面SPPに較べ高波数側に傾 いており，その程度はPMMA膜厚が厚い試料に対して より大きい. $\mathrm{Ag}$ 膜厚は金属側へのSPP侵入長 $(11 \mathrm{~nm})$ よ り十分厚いためSi基板の影響は小さく, 分散曲線に生じ た変化はAg表面のPMMA層により誘起されたものと解 釈できる。先に論じたように, PMMA膜のコートによ り $\mathrm{Ag}$ 表面領域の実効的な誘電率は膜厚に応じた上昇を 呈する. SPP分散曲線の高波数側への変位はこれにより 生じたものであり, その結果ライトラインとの波数の差 $\Delta k$ の増大とビート波長 $\lambda_{\text {beat }}$ の短縮がもたらされる.

導出したSPP分散曲線から $\omega_{0}$ におけるSPP波長を見積 もり，Eq.（1）を用いてPMMA:100 nm/Ag:40 nmおよび PMMA:20 nm/Ag:100 nmの各試料について $\lambda_{\text {beat }}$ の $\theta$ 依存性 を計算した結果が，それぞれFig. 3 (c) およびFig. 4 (c) の実線である，双方とも実験值の傾向を良く再現してお り，このことから4層モデルを用いてのSPP波長の定量 的な算出が可能であることが分かる. また, SPPの励起 光はフェムト秒レーザーであり $100 \mathrm{~nm}$ 以上のスペクト ル幅を有するが, 励起されるSPP波長の導出には搬送波 振動数 $\omega_{0}$ における值を引用すれば良いことが分かる。今 回の試料における光-SPP結合部は構造が単純な $\mathrm{Ag}$ 薄膜 エッジであり，共鳴的な構造を特に持たないため, レー ザーのスペクトル成分の光-SPPの結合強度や両者間の 位相関係はスペクトル領域 $(700-900 \mathrm{~nm})$ に渡りそれ程

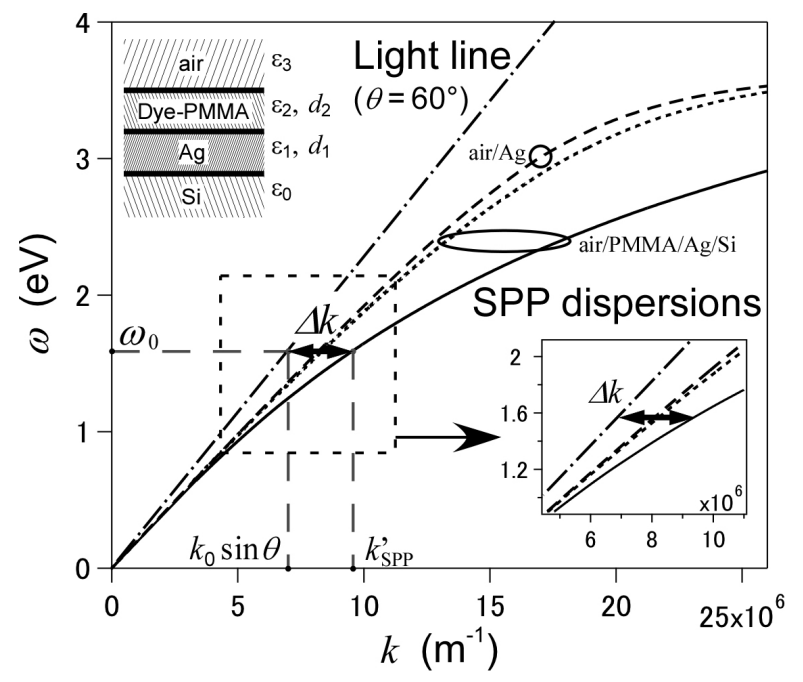

Fig. 5 Dispersion curves of SPPs for air/PMMA(100 nm)/ $\operatorname{Ag}(40 \mathrm{~nm}) / \mathrm{Si}$ layers (solid line), air/ PMMA $(20 \mathrm{~nm}) / \operatorname{Ag}(100 \mathrm{~nm}) / \mathrm{Si}$ layers (dotted line), and air/Ag layers (dashed line). A light-line for the incident angle at $60^{\circ}$ is also shown (dasheddotted line). The inset is a magnification of dispersions near the carrier-wave frequency of the fs laser.
変化しないと考えられる。そのため, 励起されるSPP波 束の形状は励起パルスの搬送波の振動形状を反映した, 励起パルス同様のフェムト秒時間幅の波束になる。従っ て励起パルスにチャープや位相変調がなければ，励起光 とSPPとの干渉ビートは試料表面上で一定のピッチで現 れ，Fig. 4，5に見られるように顕微像からビート波長を 確定する事が可能になる

フェムト秒レーザーの利用は, 多光子励起過程による 表面場のアップコンバージョンをより容易にする。一般 に多光子過程の次数は励起光強度に対する信号強度の変 化から判断されるが, SPPはTM波でのみ励起されると いう選択性を利用し, 信号強度の偏光依存性から次数を 決定する事が可能である。Fig. 6 (a)に，C343蛍光膜試 料(PMMA: $20 \mathrm{~nm} / \mathrm{Ag}: 100 \mathrm{~nm}$ ) に対し励起光の入射角を $\theta=75^{\circ}$ に固定し, 偏光面の角度 $(\phi)$ に対するビート信号 強度の依存性を計測した結果を示す。ビートパターンの 振幅はP-偏光 $\left(\phi=0^{\circ}\right)$ で最大であり, s偏光 $\left(\phi=90^{\circ}\right)$ に近 づくにつれ減衰し, 平坦な背景強度へと収束する。 Fig. 6 (b)に, エッジ部に最も近いビートのピーク強度 (Fig. 6 (a) 点線)の偏光依存性を示す。信号強度の $\phi$ 依存性は, $\cos ^{2} \phi$ (Fig. 6 (b) 点線) とは有意な差があり, $\cos ^{4} \phi$ (実線) に良く従う事から, $\mathrm{Ag}$ 表面の蛍光層の発光は実際に表 面場の2光子吸収によるものである事が確認できる.

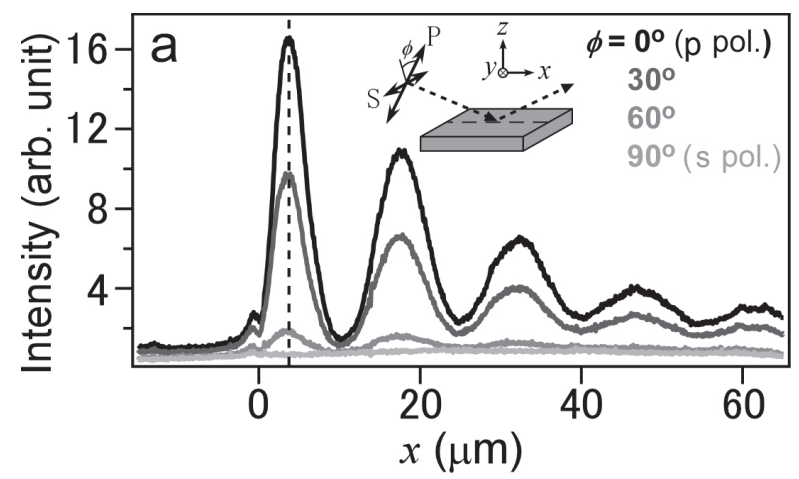

$b$

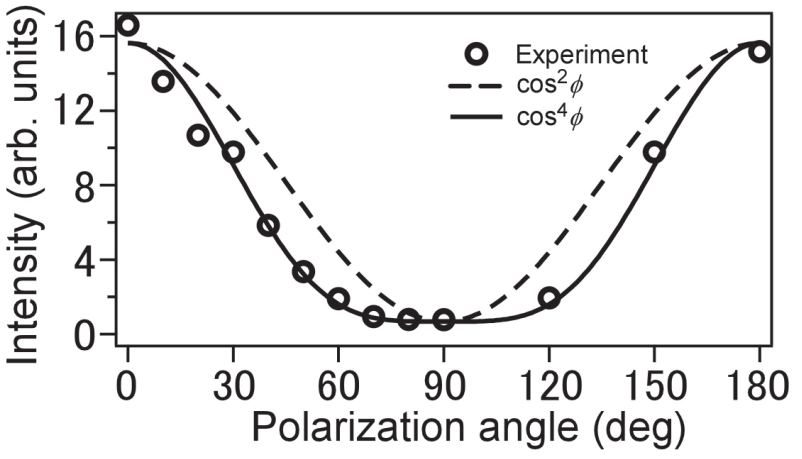

Fig. 6 (a) Intensity profiles of beat patterns taken with the polarization angle $\phi$ at $0^{\circ}$ ( $\mathrm{p} \mathrm{pol}$.), $30^{\circ}, 60^{\circ}$, and $90^{\circ}$ (s pol.). The light incident angle $\theta$ is fixed at $75^{\circ}$. The sample used is same as that shown in Fig. 4 (b). (b) Polarization angle dependence of the beat intensity (open circle) measured at the position indicated by the dashed line in (a). Functions of $\cos ^{2} \phi$ (dashed line) and $\cos ^{4} \phi$ (solid line) are also shown to guide eyes. 
フェムト秒レーザーを励起光に用いた事による, cw レーザー励起の場合との違いは, 特にビートの減衰距離 に顕著に表れる。Fig. 4 (b) に示すビートパターンは, $\theta=45^{\circ}$ では $x \sim 20 \mu \mathrm{m}$ でほぼ振動が消失しているが, この 長さはSPP波数べクトルの虚部から予測されるSPPの伝 搬距離 $(\sim 200 \mu \mathrm{m})$ に較べ有意に短い。加えて，ビート の減衰距離は $\theta$ の増大とともに伸び, $\theta=62^{\circ}$ では $x \sim$

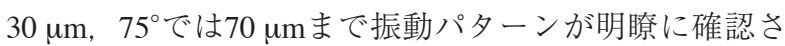
れる。これらの特徵は, SPP-励起光干渉の生じる領域 の空間的な広がりが，励起光パルスの時間幅と入射角に よって制限される事を反映したものである. Fig. 5に示 したように, SPPの分散曲線はライトラインに較べ高波 数側へカーブした形状をしており, 群速度 $\left(v_{\mathrm{SPP}}=\right.$ $d \omega / d k)$ は光速より遅く, Fig. 4に示す試料では $v_{\mathrm{SPP}}=0.97 c$ ( $c$ : 光速) と見積もられる。一方, 励起パルスの波面が 試料表面を前進する速度は $c / \sin \theta$ で与えられるため, ど の角度においてもSPPの群速度よりも高速となる。この ため, エッジ部から進行するにつれSPP波束と励起パル スとの距離は開いていき，それに伴い干渉ビートの振幅 は減衰する。加えて, 励起パルス波面の前進速度は $\theta$ が 減少するにつれて増大するため, 干渉ビートの減衰は入 射角が小さいほどより強調されたものになる。 Fig. 4 (b)に見られるビートの減衰距離は, このように フェムト秒レーザーを用いたことによるSPP-励起光干 渉領域の空間的な制限を反映したものであり，同じく フェムト秒パルスを光源に用いたPEEMによるSPP観察 の報告と類似する ${ }^{7,21)}$ 。この結果は, cwレーザー励起の 場合にビートの減衰距離はSPPの伝搬距離を直接反映す るものである事と, 強い対比をなす, ${ }^{6,14}$. ダブルパルス 化した励起光を用いるフェムト秒時間分解法を適用する 事で, 本報告で示した二光子蛍光顕微鏡法によるSPP波 束伝搬の映像化が可能である事が示唆される.

\section{4. まとめ}

フェムト秒レーザー励起二光子蛍光顕微鏡法により $\mathrm{Ag}$ 膜表面に励起されたSPPの画像化を行った。 Ag膜の エッジ部で励起されたSPPは励起光と干渉し，表面場の ビートを形成する。 $\mathrm{Ag}$ 表面に形成した蛍光薄膜が表面 場の二光子過程により励起される結果, ビートの強度分 布を光学顕微鏡により画像化する事が可能となる。観測 したビートパターンが実際にSPP-光干渉に由来するも のである事は, ビート強度が励起光の偏光に対して予測 される依存性を示すこと, ビート波長は蛍光分子の種 類・蛍光波長に依らず表面層の誘電率分布が同じならば 同一であること，ビート波長が表面プラズモン波長と光 の入射角から予測される值と定量的に一致することから 確認した。当手法はポンプープローブ法と組み合わせる 事によりSPP波束ダイナミクスの動的な映像化に適用で き, 特に従来有効な方法のなかった近赤外領域のSPP波
束の映像化を可能にすることから，複雑な導波路構造を 有するプラズモニックデバイスの評価や，能動素子の基 礎となるプラズモンー多準位系相互作用ダイナミクス観 測を行うための有用な手段を提供するものと考えられ る.

\section{謝 辞}

本研究は科学技術振興機構さきがけ，科研費 （21020006，23760044）の支援を受けて行われた。

\section{参考文献}

1) W. L. Barnes, A. Dereux, and T. W. Ebbesen: Nature 424 (2003) 824

2) S. A. Maier: Plasmonics: Fundamentals and Applications. (Springer, 2007)

3) D. K. Gramotnev and S. I. Bozhevolnyi: Nature Photon. 4 (2010) 83.

4) D. M. Koller, A. Hohenau, H. Ditlbacher, N. Galler, N. Reil, F. R Aussenegg, A. Leitner, E. J. W. List, and J. R. Krenn: Nature Photon. 2 (2008) 684.

5) A. L. Falk, F. H. L. Koppens, C. L. Yu, K. Kang, N. de Leon Snapp, A. V. Akimov, M.-H. Jo, M. D. Lukin, and H. Park: Nature Phys. 5 (2009) 475.

6) L. Yin, V. K. Vlasko-Vlasov, A. Rydh, J. Pearson, U. Welp, S.-H Chang, S. K. Gray, G. C. Schatz, D. B. Brown, and C. W. Kimball: Appl. Phys. Lett. 85 (2004) 467.

7) A. Kubo, K. Onda, H. Petek, Z. Sun, Y. S. Jung, and H. K. Kim: Nano Lett. 5 (2005) 1123.

8) A. Kubo, N. Pontius, and H. Petek: Nano Lett. 7 (2007) 470 .

9) A. Kubo, Y. S. Jung, H. K. Kim, and H. Petek: J. Phys. B: At. Mol. Opt. Phys. 40 (2007) S259.

10) L. Zhang, A. Kubo, L. Wang, H. Petek, and T. Seideman: Phys. Rev. B 84 (2011) 245442.

11) M. Aeschlimann, T. Brixner, A. Fischer, C. Kramer, P. Melchior, W. Pfeiffer, C. Schneider, C. Strüber, P. Tuchscherer, and D. V. Voronine: Science 333 (2011) 1723

12) H. Ditlbacher, J. R. Krenn, N. Felidj, B. Lamprecht, G. Schider, M. Salerno, A. Leitner, and F. R. Aussenegg: Appl. Phys. Lett. 80 (2002) 404.

13) H. Ditlbacher, J. R. Krenn, G. Schider, A. Leitner, and F. R. Aussenegg: Appl. Phys. Lett. 81 (2002) 1762.

14) B. Wang, L. Aigouy, E. Bourhis, J. Gierak, J. P. Hugonin, and P. Lalanne: Appl. Phys. Lett. 94 (2009) 011114.

15) T. Hattori, A. Kubo, K. Oguri, H. Nakano, and H. T. Miyazaki: Jpn. J. Appl. Phys. 51 (2012) 04DG03.

16) B. Lamprecht, J. R. Krenn, G. Schider, H. Ditlbacher, M. Salerno, N. Felidj, A. Leitner, F. R. Aussenegg, and J. C. Weeber: Appl. Phys. Lett. 79 (2001) 51.

17) H. Raether: Surface Plasmons on Smooth and Rough Surfaces and on Gratings (Springer, Berlin, 1988).

18) P. B. Johnson and R. W. Christy: Phys. Rev. B 6 (1972) 4370

19) P. Berini, R. Charbonneau, N. Lahoud, and G. Mattiussi: J. Appl. Phys. 98 (2005) 043109.

20) A. Stingle, G. Spielmann, F. Krausz, and R. Szipöcs: Opt. Lett. 19 (1994) 204.

21) L. Zhang, A. Kubo, L. Wang, H. Petek, and T. Seideman: Phys. Rev. B 84 (2011) 245422.

22) I. Pockrand: Surf. Sci. 72 (1978) 577

23）岡本 隆之，梶川 浩太郎：プラズモニクス＼cjkstart基礎と応用（講 談社, 2010).

24) Palik: Handbook of Optical Constants of Solids (Academic, New York, 1998). 